\title{
FACTORS THAT AFFECT THE AUDITOR'S INTENTION TO DO WHISTLEBLOWING IN SUPREME AUDIT INSTITUTION
}

\author{
Hendry Tanuwijaya \\ Christian Satya Wacana University \\ 232016504@student.uksw.edu
}

\begin{abstract}
The high number of fraud that occurs makes many people doubt the performance of an auditor. Whistleblowing or the disclosure of fraud is believed more effective to overcome this phenomenon. This research aims to look at the influence of Attitude Toward Behavior, Subjective Norm, Perceived Behavioral Control, and Personal Cost on the Auditors' Intention to do the Whistleblowing. By using multiple regression analysis, this research has an object of Supreme Audit Institution of Central Java. As many as 60 samples obtained from filling out the questionnaires, the result shows that attitude toward behavior and subjective norm have effect on auditors' intention to do the whistleblowing. However, perceived behavior control and personal cost have no effects auditors' intention to do whistleblowing.
\end{abstract}

Keywords: attitude toward behavior; perceived behavioral control; personal cost; subjective norm; whistleblowing intention

\section{INTRODUCTION}

Fraud becomes a dangerous thing and also a threat to an organization. Certified Fraud Examiners (ACFE) classifying fraud into misappropriation in assets, fraudulent statements, and corruption (Tuanakotta, 2014). From many fraud cases that happened inside or outside the countries, it makes the professionalism, independence, ethics of an accountant are being questioned. So, another way to deal with fraud and to bring back the people's trust to an accountant is to do whistleblowing (Merdikawati, 2012). Whistleblowing is an activity that can be done by someone or a group of people to revealed fraud that their colleagues have done. Whistleblowing has a major role in uncovering fraud that occurs in public or private institutions. Based on LKPP No. 11, 2004 a whistleblower is someone from the internal of the organization or institution who has the information or access to report any fraud that happened at their workplace.

Theory of Planned Behaviour (TPB) is a reference for this research. This theory shows the forming of someone's behavior (Lestari \& Yaya, 2017). Several studies have been done to ensure the factors that make an auditor do whistleblowing both inside and outside the country. Heungsik Park \& Blenkinsopp (2009) use the Theory of Planned Behavior as their base theory to see its relation to whistleblowing. Mesmer- Magnus \& Visweswvaran (2005) in (Nurkholis, 2015) researched 
about factors that affect someone to whistleblowing with one of the factors is a personal cost.

This research aims to analyze the factors that can affect auditors in doing whistleblowing. Later, the benefit of this study is to increase the professionalism of the auditors and as a consideration in recruiting the new auditors. For the students, it helps them to recognize the importance of revealing the fraud. For the next researchers, this can be used as an ante to further accounting research.

\section{LITERATURE REVIEW}

\subsection{Theory of Planned Behaviour}

In this research, the Theory of Planned Behaviour becomes a basic reference. Developed from the Theory of Reasoned Action, this theory explains a relationship between the readability of someone with the behavior and how the behavior can be formed. Ajzen (1991) categorizes three types that together will form the individual behavior intention and intention. Namely attitude toward behavior; Subjective norm; Perceived behavioral control. Rustiarini \& Sunarsih (2017) stated that attitude toward behaviour is about someone's point of view through things while subjective norm is about someone's point of view on a particular behavior, and Perceived behavioral control is someone's point of view in controlling their particular behavior which relates with the level of ease and difficulty in the way of doing something.

\subsection{Whistleblowing}

Whistleblowing is an act to reveal information neither private or public organization to disclose cases (Kumar \& Santoro, 2017). Someone who does whistleblowing starts from intention and it is called a whistleblower.
Many studies were done by experts, (Nayir \& Herzig, 2012; H. Park, Rehg, \& Lee, 2005) found factors that encourage whistleblowing from an individual's perception. Based on the previous research, this research focuses on the factors that influence the auditor's intention to conduct whistleblowing in the way of individual perception. An Individual's perception will relate to attitudes toward behavior, subjective norms, perceived behavioral control, and personal cost.

\subsection{Personal Cost}

Personal cost can be likened to something that needs to pay after doing something. Personal cost is someone's point of view about the risk when they report some wrongdoing done by their colleague (Nurkholis, 2015). The risk can come from every party, it can be in the form of salary reduction, discrimination or even resign (Curtis, 2006) in (Nurkholis, 2015). The bigger someone's perception of personal cost, it will make them more afraid to report some fraud or suspicious things to the authorities.

\subsection{Hypothesis Development}

\subsubsection{Attitude toward Behavior as a Factor to Do Whistleblowing}

In this study, attitude toward behavior is regarded as an independent variable that will affect someone's behavior such as whistleblowing.

Previous scholars show that attitude toward behavior affects the intention to do whistleblowing (Alfani, 2016; Hays, 2013; Heungsik Park \& Blenkinsopp, 2009). The first hypothesis states that,

H1: Attitude toward behavior has a positive effect on the auditors' intention to do whistleblowing. 


\subsubsection{Subjective Norm as a Factor to Do Whistleblowing}

Subjective norm is about someone's perspective to do something that is influenced by internal and external parties. Subjective norms also have a positive effect on the auditor's intention to conduct whistleblowing (Hays, 2013; Heungsik Park \& Blenkinsopp, 2009). The second hypothesis states that, $\mathrm{H} 2$ : Subjective norm has a positive effect on the auditors' intention to do whistleblowing.

\subsubsection{Perceived Behavioral Control as a Factor to Do Whistleblowing}

This variable can be defined as the level of ease of someone to take action. Ajzen (2012) and Alfani (2016) stated that someone will do an action when there are social pressure and an opportunity and it becomes a strong determinant of someone to do something.

The research was done by Azwar \& Saragih (2018) and Rustiarini \& Sunarsih (2017) with government institutions as their object, proves that perceived behavioral is one of the factors influencing the intention to do whistleblowing. The third hypothesis states that,

H3: Perceived behavioral control has a positive effect on the auditors' intention to do whistleblowing.

\subsubsection{Personal Cost as a Factor to Do Whistleblowing}

Winardi (2013) assumed that when someone has high knowledge about personal cost they will know more about the future risk. This phenomenon makes someone rarely report any wrongdoing done by their friends.

The research was done by Nurkholis (2015) and Winardi ( 2013) does not prove that personal cost can influence the intention to do whistleblowing. The fourth hypothesis states that,

$\mathrm{H} 4$ : Personal cost has a negative effect on the auditors' intention to do whistleblowing

\section{RESEARCH METHOD}

Based on the hypothesis made, the researcher forms a theoretical framework as shown in figure 2 . This is quantitative research where it needs to analyze several data in the form of numbers to get any connection. This study analysis method uses SPSS.

\subsection{Data Collection Techniques}

This research uses primary data sources from the questionnaires fulfilled by the respondents. The respondents of this study are all auditors who work in Supreme Audit Institution Central Java.

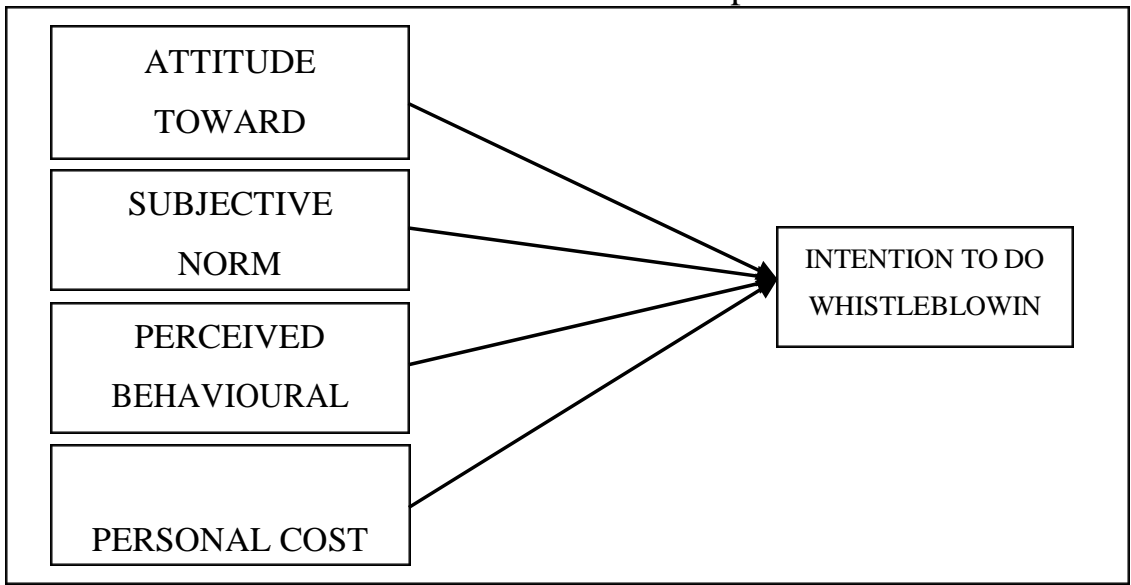

* Corresponding author's e-mail: 232016504@student.uksw.edu 
Figure 2: Theoretical Framework Source: Writer (2019)

In this study, the writer doesn't make his own questionnaire but adopt it from the previous research. To clarity each variable, the writer tries to define each variable and give measurement based on previous research where uses five Likert scales were used for each measurement. It can be described in Table 1 below:

Table 1: Five Likert Scale

\begin{tabular}{c|c}
\hline Scale & Definition \\
\hline 1 & Totally Disagree \\
\hline 2 & Disagree \\
\hline 3 & Neutral \\
\hline 4 & Agree \\
\hline 5 & Totally Agree \\
\hline
\end{tabular}

Table 2: Operational Definition

\begin{tabular}{|c|c|c|}
\hline Variable & Definition & Indicator \\
\hline $\begin{array}{l}\text { Attitude toward } \\
\text { behavior }\end{array}$ & $\begin{array}{ll}\text { Auditor's } & \text { judgments } \\
\text { whistleblowing. (Alfani, 2016) }\end{array}$ & $\begin{array}{ll}\text { 1. } & \text { Acceptable act } \\
\text { 2. } & \text { Positive action } \\
\text { 3. } & \text { Ethical behavior } \\
\text { 4. } & \text { Benefits } \\
\text { 5. } & \text { Pride }\end{array}$ \\
\hline Subjective norm & $\begin{array}{l}\text { Auditor's perspective } \\
\text { whistleblowing. (Alfani, 2016) }\end{array}$ & $\begin{array}{ll}\text { 1. } & \text { Personal's } \\
& \text { perspective } \\
\text { 2. } & \text { Other's perspective } \\
\text { 3. } & \text { Environment's } \\
& \text { opinion }\end{array}$ \\
\hline $\begin{array}{l}\text { Perceived behavior } \\
\text { control }\end{array}$ & $\begin{array}{l}\text { Auditor's belief that behavior } \\
\text { comes from their control. (Alfani, } \\
\text { 2016) }\end{array}$ & $\begin{array}{l}\text { 1. The probability } \\
\text { 2. Personal desire } \\
\text { 3. Personal control } \\
\text { 4. Someone's } \\
\text { convenience }\end{array}$ \\
\hline Personal cost & $\begin{array}{l}\text { The risks that might be happened } \\
\text { to the auditor as a result of } \\
\text { reporting wrongdoing. (Winardi, } \\
\text { 2013) }\end{array}$ & $\begin{array}{ll}\text { 1. } & \text { Personal risk } \\
\text { 2. } & \text { Threat level }\end{array}$ \\
\hline $\begin{array}{l}\text { Intention to do } \\
\text { Whistleblowing }\end{array}$ & $\begin{array}{l}\text { Someone's desire to whistle out } \\
\text { any frauds. } \\
\text { (Winardi, 2013) }\end{array}$ & $\begin{array}{ll}\text { 1. } & \text { Report with identity } \\
\text { 2. } & \text { Behavioral belief } \\
\text { 3. } & \text { Intention level }\end{array}$ \\
\hline
\end{tabular}




\subsection{Operational Definitions of Variables}

In this research, the writer uses one dependent variable which is the act of doing whistleblowing (Y1) and four independent variables which are attitude toward behavior (X1), subjective norm (X2), perceived behavioral control (X3) and the personal cost (X4).

\subsection{Sample Collection Techniques}

This research uses a quantitative method and the objects are the auditors who work in the Supreme Audit Institution of Central Java. The writer uses a saturation sampling method to get the data. The saturation sampling method is a technique to use all of the population as the research sample. The reason why the writer uses this method is that there are limited respondents. Based on the data as of September 2018 the total number of auditors in Supreme Audit Institution Central Java (Semarang) was 143.

\subsection{Data Analysis Techniques}

In this research, the data analysis method used is multiple linear regression. But before making a multiple linear regression analysis there are several steps to do, such as (1) Validity and Reliability test, (2) Classic Assumption test which includes normality test, multicollinearity test, and heteroskedasticity test. After all preliminary, the steps have been passed the next step is to do a hypothesis testing by using multiple linear regression formula, $\mathrm{t}$ statistic test, and $\mathrm{F}$ statistic test.

\subsubsection{Validity and Reliability Test}

Validity test is used to see whether each of the questions is valid or not. A set of the questionnaire can be claimed as valid if the significance value $>0.05$ (Ghozali, 2011). Reliability test is used to see whether the question is reliable or not. A questionnaire can be claimed as reliable if it provides consistent results and the Cronbach alpha value > 0.70 (Ghozali, 2011).

\subsubsection{Classic Assumption Test}

Classic assumption test is used to provide certainty about the regression equation which consists of (1) Normality test, (2) heteroskedasticity, and (3) multicollinearity test.

The multiple linear regression formula is as

follows:

$$
\begin{gathered}
Y=\alpha+\beta 1 X 1+\beta 2 X 2+\beta 3 X 3 \\
+\beta 4 X 4+e
\end{gathered}
$$

$\mathrm{Y}=$ to do whistleblowing (dependent variable)

$\alpha=$ constanta

$\beta 1, \beta 2, \beta 3, \beta 4=$ regression coefficient

$\mathrm{X} 1=$ attitude toward behavior (independent variable)

$\mathrm{X} 2$ = subjective norm (independent variable)

$\mathrm{X} 3=$ perceived Behavior Control (independent variable

$\mathrm{X} 4=$ personal Cost (independent variable)

$\mathrm{e}=$ error

\section{RESULTS AND DISCUSSION 4.1. Results}

Based on the survey there were only 112 auditors because most of them went for audit service out of town. So, only 112 questionnaires were distributed to the auditors and after two weeks there were only 60 questionnaires returned or $53,57 \%$.

The first tests to be done are the validity and reliability test. In this test, the writer uses the Pearson Correlation. A 
set of the questionnaire can be claimed as valid if the significance value is greater than 0.05 (Ghozali, 2011). Based on the analysis for each question from each variable shows that the value of the Pearson Correlation is greater than 0.05 . It means that the questionnaires can be categorized as valid.

The next step is the reliability test. A questionnaire can be claimed as reliable if it provides consistent results and the Cronbach's Alpha value is greater than 0.70 (Ghozali, 2011). Based on the result of the reliability test for each question from each variable, it can be categorized as reliable. It is proved with the value of the Cronbach's Alpha which is greater than 0.70 .
After completing the validity and reliability test, the next step is to verify the normality, heteroskedasticity, and multicollinearity. The data which more than $30(\mathrm{n}>30)$ is assumed as normal (Ghozali, 2011). In this research the normality test uses Asymp. Sig. (2-tailed) in which the result is $.200^{\mathrm{d}}$ It means that the data can be claimed as normal because it is greater than 0.05 .

The next test is heteroscedasticity. The result of the heteroscedasticity test is based on the scatterplot test. The data can be considered as having no problem with heteroscedasticity if the dots on the scatterplot graph spread without forming a clear pattern. Table 6 shows the result of heteroscedasticity where all the dots are spread without forming a pattern.

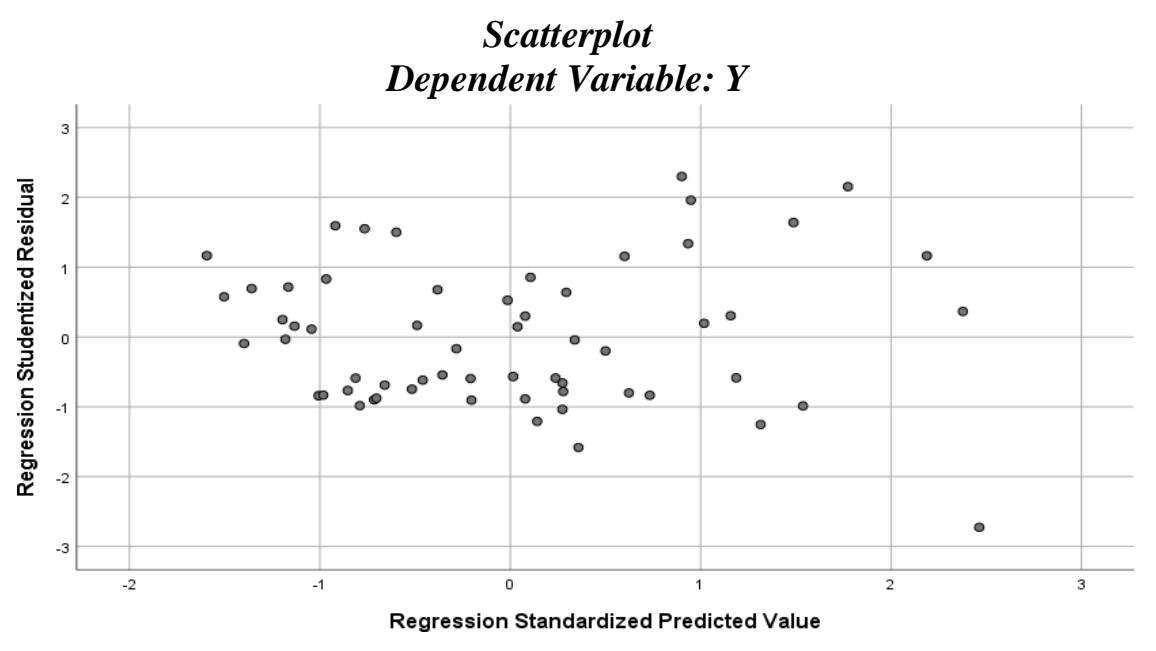

Figure 3: Heteroscedasticity Test Result Source: Based on the primary data

Multicollinearity test is used to see whether there is any correlation between independent variables or not. This assessment is based on VIF and tolerance value. When the value of tolerance is above 0.01 and the value of VIF is below 10 the data can be considered to have no problem with multicollinearity. Based on the multicolinearity test result, it can be concluded that there is no problem with multicolinearity test because the value of tolerance and VIF for each independent variable is above 0.01 and below 10 .

The next step is multiple linear regression analysis which used to see the relationship between independent variables through the dependent variable. The result of multiple linear regression analysis is presented in Table 7 as follows 
Table 7: Multiple Linear Regression Analysis

\begin{tabular}{rrrrr}
\hline & $\begin{array}{c}\text { Coefficients } \\
\text { Unstandardized }\end{array}$ & & & \\
Model & $\begin{array}{c}\text { Adjusted R } \\
\text { Square }\end{array}$ & F & \multicolumn{1}{c}{ t } \\
\hline 1(Constant) & -5.209 & & & -2.415 \\
X1 & .198 & & & 2.498 \\
X2 & .172 & .665 & $($ sig: 0.000$)$ & 2.294 \\
X3 & .045 & & &, 513 \\
X4 & 1.126 & & & 8,980 \\
\hline
\end{tabular}

Source: Based on the primary data

Based on the table can be found the equation $\mathrm{Y}=-5.209+0.198 \mathrm{X} 1+$ $0.172 \mathrm{X} 2+0.045 \mathrm{X} 3+1.126 \mathrm{X} 4+\mathrm{e}$.

The next step is to analyze the coefficient determination based on Rsquare. The result of $\mathrm{R}$ square is 0.665 means that the contribution or the relationship between the independent variable and dependent variable is $66.5 \%$, in which $33.5 \%$ is based on other factors.

The next step is a partial significance test (t statistic). $\mathrm{T}$ statistic test is completed by looking at the comparison between $t$ count and $t$ table. When Tcount $>$ Ttable the hypothesis accepted. On the other hand, if Tcount > Ttable the hypothesis rejected.

The value of Ttable for the probability of 0.05 with $n=60$ is 1.67303. Based on the result from Table 7, attitude toward behavior (X1), subjective norm (X2), and personal cost (X4) have a greater value of Tcount which means it has a positive effect on the dependent variable. While for perceived behavioral control, the lower Tcount number which means it has no effect on the dependent variable.

Simultaneous test is completed by comparing the number of significance and then compare the Fcount with Ftable. If Fcount > Ftable and the value of significant is
0.05 , it can be interpreted that the independent variables have simultaneously effect on its dependent, reversely. The value of Ftable with the value of significant is 0.05 an $n=60$ is 2.54. Based on tests, it shows that the value of Fcount > Ftable with the significant level is 0.000. This shows that all independent variables simultaneously effect its dependent.

\subsection{Discussion}

This research used a sample of 60 auditors of the Audit Supreme Institution. The dependent variable is the act of doing whistleblowing (Y1) and four independent variables are attitude toward behavior (X1), subjective norm (X2), perceived behavioral control (X3), and the personal cost (X4). The researcher uses the classic assumption test and multiple linear regression. Also, Ftest and t-test for hypothesis testing.

\subsubsection{Attitude Toward Behavior}

Based on partial significant test shows that attitude toward behavior (X1) has a positive effect on the intention to do whistleblowing. Therefore, the first hypothesis is accepted. 
EAJ (Economics and Accounting Journal) - Vol. 3, No. 2, May 2020 - Tanuwijaya

The outcome of this research is the same as those of Alfani (2016); Hays (2013); and Heungsik Park \& Blenkinsopp (2009) which states that the attitude toward behavior or someone's attitude has a positive effect on the auditor's intention to do whistleblowing.

\subsubsection{Subjective Norm}

Based on partial significance test the second hypothesis is accepted. It means the result of the research can confirm the Theory of Planned behavior where people will do an action by looking at things that are affected. This is in accordance with the research of Hays (2013); Heungsik Park \& Blenkinsopp (2009); and Azwar \& Saragih (2018) where the subjective norm has a positive effect on the auditor's intention to do whistleblowing.

\subsubsection{Perceived Behavioral Control}

The result shows that perceived behavioral control has no effect on the intention to do whistleblowing. Therefore, the third hypothesis is rejected. It means perceived behavioral control not always bring an impact on whistleblowing intentions at work.

Therefore, this outcome is not accordance with the research of Azwar \& Saragih (2018) and Rustiarini \& Sunarsih (2017) where they explained that perceived behavior affects the intention to do whistleblowing.

\subsubsection{Personal Cost}

Based on the partial significance test, the fourth hypothesis that personal cost has a positive effect on the auditor's intention to do

whistleblowing is rejected. It means that respondents are willing to report any fraud that might be happened in their workplace. This phenomenon can be caused by a strong level of auditor independence. Also, there is already a whistleblowing system in the Supreme Audit Institution which can be accessed easily by the auditor to report any wrongdoing that happened without being identified.

\section{CONCLUSION}

Based on the results, among the four hypotheses that were designed it can be in the draw of conclusion as follows:

1. Attitude Toward Behavior (X1) has positive effect on the auditor's intention to do whistleblowing.

2. Subjective norm (X2) has positive effect on the auditor's intention to do whistleblowing.

3. Perceived behavior control has no effect on the auditor's intention to do whistleblowing

4. Personal cost has positive effect on the auditor's intention to do whistleblowing.

There are still some limitations to this research. Some auditors are carrying out service outside the office, so questionnaires distributed not to be fully returned. In the future, this research can be developed by using different objects or variables or using a different theoretical framework. However, the Audit Supreme Institution must continue to maintain and keep emphasizing the importance of whistleblowing act to prevent fraud. 


\section{REFERENCES}

Ajzen, I. (1991). The Theory of Planned Behavior. Organizational Behavior and Human Decision Process, 50, 179-211. https://doi.org/10.1922/CDH_2120 VandenBroucke08

Ajzen, I. (2012). The theory of planned behavior, In P. A., Lange, A. W. Kruglanski, \& E. T. Higgins (Eds.). Handbook of theories of social psychology. London, UK.

Alfani, U. N. (2016). Persepsi Mahasiswa Akuntansi Terhadap Niat Melakukan Whistleblowing.

Azwar, I., \& Saragih, R. (2018). The Influence of Attitude Toward the Behavior, Subjective Norm, and Perceived Behavioral Control on Whistle-blowing Intention.

Curtis, M. B. (2006). Are Audit-related Ethical Decisions Dependent upon Mood? Journal of Business Ethics, 68, 191-209.

Ghozali, I. (2011). Analisis Statistik dengan SPSS 19.

Hays, J. B. (2013). An investigation of the motivation management accountants to report fraudulent accounting activity: applying The Theory of Planned Behavior. Nova Southeastern University, Florida.

Kumar, M., \& Santoro, D. (2017). A justification of whistleblowing. Philosophy Dan Social Criticism, 43(7), 669-684.

Lestari, R., \& Yaya, R. (2017). Whistleblowing Dan Faktor-Faktor Yang Mempengaruhi Niat Melaksanakannya Oleh Aparatur Sipil Negara. Jurnal Akuntansi, 21(3), 336. https://doi.org/10.24912/ja.v21i3.2 65

Merdikawati, R. (2012). Hubungan Komitmen Profesi dan Sosialisasi Antisipatif Mahasiswa Akuntansi dengan Niat Whistleblowing (Studi Empiris pada Mahasiswa Strata 1
Jurusan Akuntansi di Tiga Universitas Teratas di Jawa Tengah dan D.I Yogyakarta).

Mesmer- Magnus, J. R., \& Visweswvaran, C. (2005). Whistleblowing in organizations: An examination of correlates of whistleblowing intentions, actions, and retaliation. Journal of Business Ethics, 6(3), 227-297. https://doi.org/doi: $\quad 10.1007 /$ s10551-005-0849-1

Nayir, D. Z., \& Herzig, C. (2012). Value Orientations as Determinants of Preference for External and Anonymous Whistleblowing. Journal of Business Ethics, 107(2), 197-213. https://doi.org/10.1007/s10551011-1033-4

Nurkholis, R. B. (2015). Faktor-faktor yang mempengaruhi minat pegawai negeri sipil (PNS) untukmelakukan tindakan whistleblowing (Studi pada PNS BPK RI). Jurnal Ekonomi Dan Keuangan, 19(2), 276-295.

Park, H., Rehg, M. T., \& Lee, D. (2005). The influence of Confucian ethics and collectivism on whistleblowing intentions: A study of South Korean public employees. Journal of Business Ethics, 58(4), 387-403. https://doi.org/doi: 10.1007/s10551- 004-5366-0

Park, Heungsik, \& Blenkinsopp, J. (2009). Whistleblowing as planned behavior - A survey of south korean police officers. Journal of Business Ethics, 85(4), 545-556. https://doi.org/10.1007/s10551008-9788-y

Rustiarini, N. W., \& Sunarsih, N. M. (2017). Factors Influencing the Whistleblowing Behavior: A Perspective from the Theory of Planned Behaviour. Asian Journal of Business and Accounting, 10(2), 
EAJ (Economics and Accounting Journal) - Vol. 3, No. 2, May 2020 - Tanuwijaya

65-70.

Tuanakotta, T. M. (2014). Akuntansi Forensik dan Audit Investigatif.

Winardi, R. D. (2013). The Influence of Individual and Situational Factors on Lower-Level Civil Servants' Whistle- Blowing Intention in Indonesia. Journal of Indonesian Economy and Business, 28(3),361376. 